\title{
Escherichia coli-induced inflammation changes the expression of acetylcholine receptors (M2R, M3R, and a-7 nAChR) in the pig uterus
}

\author{
Barbara Jana $^{1 凶}$, Jarosław Całka ${ }^{2}$, Katarzyna Palus $^{2}$, Małgorzata Sikora ${ }^{1}$ \\ ${ }^{1}$ Department of Reproductive Biology, \\ Institute of Animal Reproduction and Food Research of the Polish Academy of Sciences, 10-748 Olsztyn, Poland \\ ${ }^{2}$ Department of Clinical Physiology, Faculty of Veterinary Medicine, \\ University of Warmia and Mazury, 10-718 Olsztyn, Poland \\ b.jana@pan.olsztyn.pl
}

Received: April 27, $2020 \quad$ Accepted: October 20,2020

\begin{abstract}
Introduction: The influence of inflammation on the patterns of muscarinic 2 and 3 receptor subtypes (M2R and M3R), and $\alpha-7$ nicotinic acetylcholine receptor $(\alpha-7 \mathrm{nAChR})$ expression in the porcine uterus was investigated. Material and Methods: On day three of the oestrous cycle of gilts aged 7-8 months with body weight 90-120 kg, either an E. coli suspension (E. coli group, $\mathrm{n}=5$ ) or saline (Sal group, $\mathrm{n}=5$ ) was administered into the uterine horns via laparotomy or only laparotomy was performed on control swine ( $\mathrm{Ctrl}$ group, $\mathrm{n}=5$ ). After eight days, and the onset of severe acute endometritis in the $E$. coli group, the uterine mRNA and protein receptor expression levels were determined using real-time RT-PCR and Western blotting, respectively, with receptor localisation by immunofluorescence. Results: The studied receptors were in the luminal epithelium, glands, blood vessels, and myometrial muscle cells of all gilts. The M2R mRNA level was lower in the inflamed endometrium compared to the Ctrl and Sal groups. Also in this tissue, the expression of M3R mRNA and protein was lower than in the Ctrl and Sal groups. The M3R protein level in the bacterially challenged myometrium was found to be increased compared to unadministered groups. In the endometrium of the E. coli group, the $\alpha-7 \mathrm{nAChR}$ protein level was lower than in the Sal group, and in the myometrium it was reduced in relation to both the other groups. $P$ values were $\leq 0.05$ in all cases. Conclusion: Inflammation causes alterations in the M2R, M3R, and $\alpha-7 \mathrm{nAChR}$ expression in the pig uterus, suggesting their significance in the course and repercussions of uterine inflammation.
\end{abstract}

Keywords: pig, inflamed uterus, acetylcholine receptor, expression.

\section{Introduction}

Uterine inflammatory process is a very common condition in domestic animals and women. Metritis/endometritis is caused for the most part by bacteria colonising the endometrium. This pathological state develops as a result of disturbances in uterine involution and/or immunological reaction. Although this disorder may occur in females which have not yet given birth (after natural mating or insemination), uterine inflammation takes place predominantly after parturition $(22,30)$. During uterine inflammation the production and release of cytokines $(8,34)$ as well as other inflammatory mediators, i.e. metabolites of arachidonic acid $(12,13,22)$ are markedly increased.
The uterus in pigs is innervated by either the autonomic or the sensory part of the peripheral nervous system. The uterine parasympathetic nerve fibres derive from the paracervical ganglion (31), and in addition to acetylcholine (ACh) also contain other neurotransmitters. In the uterus, nerve fibres are present in the vicinity of blood vessels, glands, and myocytes of the myometrium (21). ACh is also released from non-neuronal cells, such as immune cells (7). ACh acts by binding to two kinds of receptor (AChR): muscarinic (mAChR) and nicotinic (nAChR). Although mAChRs are G-protein-coupled receptors, nAChRs are ligand-gated ion channels (33).

The mAChR family consists of five subtypes, M1-M5, which were detected in many tissues (5). Under physiological conditions, M2R and M3R were shown to be involved in the ACh stimulatory influence on contractility 
of the mouse myometrium (16). Similarly, ACh led to a rise in the contractility of the pig uterus $(13,17)$. In this organ, the impact of ACh is mediated by M3R, but not M2R, which was not detected in the myometrium during functional and radioligand-binding experiments (17). However, the authors found that ACh affects porcine uterine contractility through both M3R and M2R (11). It was also suggested that M3R is involved in AChinduced contractility in the canine uterine artery (25). All five mAChR subtypes are present in immune cells, indicating the participation of the cholinergic system in the modulation of immune activity (7).

To date, $10 \alpha(\alpha 1-10), 4 \beta(\beta 1-4), \gamma, \delta$, and $\varepsilon$ nAChR subunits have been discovered by molecular cloning. These receptors occur as pentamers comprised of from 1-5 different subunits and were found in neuronal and non-neuronal tissues (7). With regard to the reproductive system, $\alpha-7 \mathrm{nAChR}$ expression was revealed in normal and severe preeclampsia placentas (18) as well as in endometriotic lesions (35). This receptor participates in angiogenesis and atherogenesis (24). ACh acting by binding to the $\alpha-7 \mathrm{nAChR}$ expressed by endothelial (24) and immune (29) cells also modulates inflammatory reactions. The involvement of this receptor was documented in the course of colon (32) and lung (9) inflammations.

AChR expression and function in the inflamed uterus and parasympathetic regulation of this organ are as yet little known. Escherichia coli (E. coli) is often a primary cause of uterine inflammation in domestic animals. Thus, utilisation of this pathogen for experimental induction of endometritis in swine allows better understanding of the immuno- and neuroendocrinological mechanisms underlying uterine inflammation. The experimental model applied here is relevant to naturally occurring uterine pathology. The current study found that ACh reduces the contractile activity of the inflamed porcine uterus through M2R and M3R activity (11). We hypothesised that uterine inflammation changes the expression of M2R and M3R as well as $\alpha-7 \mathrm{nAChR}$. It may condition the ACh influence on the inflammatory process and the function of the inflamed uterus and, consequently, on the course of this disease. Therefore, in the current research, the impact of the infusion of $E$. coli suspension into the gilt uterus on the levels of M2R, M3R, and $\alpha-7$ nAChR mRNA and protein expression was determined and these receptors were localised in tissue.

\section{Material and Methods}

Animals. The experiment was performed respecting the principles of animal care (National Institute of Health publication No. 86-23, revised in 1985) and the national law concerning animal protection. This research was carried out on 15 gilts (crossbred Large White $\times$ Landrace) at the age of 7-8 months and with body weight (b.w.) approximately 90-120 kg. Using a tester boar, oestrus was identified behaviourally. Disruptions in reproductive state did not occur in any of the studied pigs. Three days before the beginning of the experiment, the gilts were transported from a farm to a local piggery and they were kept there in individual pens with an area of about $5 \mathrm{~m}^{2}$ under conditions providing natural daylight for $14.5 \pm 1.5 \mathrm{~h}$ and darkness for $9.5 \pm 1.5 \mathrm{~h}$ and maintaining a temperature of $18 \pm 2{ }^{\circ} \mathrm{C}$. The animals were fed typically for the species and age and had access to water. During the experiment the animals required no treatment for health disorders.

Experimental procedure. The detailed experimental procedure, approved by the Local Ethics Committee of the University of Warmia and Mazury in Olsztyn under consent no. 31/2010 was reported previously (13). On day 3 of the second oestrous cycle (day 0 of the study), the 15 gilts were randomly divided into three equal groups: $E$. coli-administered (the $E$. coli group), saline-administered (the Sal group), and control (the Ctrl group) swine, to the last group of which no substance was administered.

Premedication with atropine (atropinum sulphuricum $0.05 \mathrm{mg} / \mathrm{kg}$ b.w. administered intramuscularly (i.m.), Polfa S.A., Poland), azaperone (Stresnil $2 \mathrm{mg} / \mathrm{kg}$ b.w., administered i.m., Janssen Pharmaceutica, Belgium), and ketamine hydrochloride (Ketamina $10 \mathrm{mg} / \mathrm{kg}$ b.w. administered intravenously (i.v.), Biowet, Poland) was carried out. General anaesthesia was induced by ketamine hydrochloride and prolonged by application of supplementary doses of this medicine $(1 \mathrm{mg} / \mathrm{kg}$ b.w. every 5 min administered i.v.). Next, the laparotomy was performed and $50 \mathrm{~mL}$ of $E$. coli suspension (strain $\mathrm{O} 25: \mathrm{K} 23 / \mathrm{a} / \mathrm{:H} 1$ from the collection of the Department of Microbiology at the National Veterinary Research Institute, Poland), containing $10^{9}$ colony-forming units $/ \mathrm{mL}$ or $50 \mathrm{~mL}$ of saline solution (for the E. coli group and Sal group, respectively) were administered into both horns of the uterus, whereas the control group had sham surgery and no substance administration. Each experimental gilt uterine horn was injected five times (10 $\mathrm{mL}$ of solution per each injection) using a syringe with a $0.8 \mathrm{~mm}$ ga needle, keeping a similar distance between the injections sites. To avoid the outflow of the solution from the uterus, soft pressure was applied with gauze to the injection sites, which were next gently wiped with the gauze and saline. To distribute bacterial suspension or saline evenly within the horns, they were carefully massaged. On day 8 of the study (the expected day 11 of the oestrous cycle) euthanasia of gilts was carried out using a lethal dose of ketamine hydrochloride administered i.v. and the uteri were collected. Next, the horns were opened along their long axis and macroscopic assessment of the endometrial layer was made. The quantity and character of inflammatory exudate and the colour, visibility of blood vessels, and presence and height of swelling in the endometrium were evaluated. Next, sections of the horn were collected from the paraoviductal, middle and paracervical parts of the uterus and reserved for real-time RT-PCR and Western blot analyses. For this purpose, endometrial and myometrial layers were divided with a scalpel. The 
separation was examined by dissecting microscope. The endometrial and myometrial sections of $1 \mathrm{~cm}$ length and one complete layer thickness were shock-frozen in liquid nitrogen and stored at $-80^{\circ} \mathrm{C}$ for real-time RT-PCR and Western blot analysis. Collection of uterine fragments, separation of both uterine layers and their freezing were carried out under sterile conditions to avoid contamination. Pieces of the uterine horns were also obtained from three parts of the organ for histological and immunofluorescent studies. They were divided into smaller pieces and fixed in $4 \%$ paraformaldehyde solution ( $\mathrm{pH} 7.4$ ). After $24 \mathrm{~h}$, the pieces were washed in $0.1 \mathrm{M}$ phosphate buffered-saline (PBS, pH 7.4). For immunofluorescent staining, tissues were cryoprotected in $18 \%$ sucrose until sectioning, and for histopathological assessment they were embedded in paraffin in the standard manner. The findings of the macroscopic and histological studies of the uteri were published previously (23).

RNA extraction, and real-time RT-PCR. Total RNA was isolated from endometrial and myometrial tissues. Tissues were homogenised in TRI Reagent solution (Invitrogen, Thermo Fisher Scientific, USA) using a FastPrep 24 homogeniser (MP Biomedicals, USA). For phase separation, BCP reagent (Molecular Research Center Inc., USA) was used, and RNA was purified by the use of the RNeasy Mini Kit (Qiagen, USA), according to the manufacturer's instructions. RNA was stored until further use at $-80^{\circ} \mathrm{C}$ in RNasefree water with the addition of RNase Inhibitor (Applied Biosystems, Thermo Fisher Scientific, USA). The quality and quantity of extracted RNA were estimated with the use of a NanoDrop 1000 spectrophotometer (Thermo Fisher Scientific, USA) and Agilent 2100 Bioanalyzer (Agilent Technologies, USA). RNA with an RNA integrity number in a 7.0-9.6 range was used in the real-time RT-PCR.

Real-time RT-PCR was carried out with TaqMan assays (Table 1) and a one-step PCR Master mix (Applied Biosystems). Each reaction $(10 \mu \mathrm{L})$ contained: $15 \mathrm{ng}$ of total RNA in a volume of $3 \mu \mathrm{L}, 5 \mu \mathrm{L}$ of $2 \times$ TaqMan RT-PCR Mix, $0.25 \mu \mathrm{L}$ of $40 \times$ TaqMan RT Enzyme Mix, $0.5 \mu \mathrm{L}$ of $20 \times$ TaqMan Gene Expression Assay and $1.25 \mu \mathrm{L}$ of RNase-free water (all Applied Biosystems). The real-time RT-PCR reaction was performed in duplicate in 384-well plates in an ABI Prism 7900HT system (Applied Biosystems) under the following conditions: reverse transcription for $15 \mathrm{~min}$ at $48^{\circ} \mathrm{C}$, initial denaturation for $10 \mathrm{~min}$ at $95^{\circ} \mathrm{C}$, and
45 cycles of $15 \mathrm{~s}$ of denaturation at $95^{\circ} \mathrm{C}$ and $1 \mathrm{~min}$ of annealing at $60^{\circ} \mathrm{C}$. The negative control was prepared by replacing the RNA template with RNase-free water. Data obtained by real-time PCR were analysed using the Miner method (37). For selection of the most stable housekeeping gene from the three of $\beta$-actin (ACTB), hypoxanthine guanine phosphoribosyl transferase (HPRT) and glyceraldehyde-3-phosphate dehydrogenase (GAPDH), the NormFinder algorithm was applied (2). Analysis indicated the best stability value for a combination of the ACTB and GAPDH genes (0.171). Therefore, the level of expression for each target gene was normalised relatively to the geometric mean of ACTB and GAPDH gene expression.

Western blotting. The M2R, M3R, and $\alpha-7 \mathrm{nAChR}$ protein expression levels in the endometrial and myometrial layers were estimated as described previously (14). Samples of the endometrium and myometrium were homogenised on ice with a cold buffer $(50 \mathrm{mmol} / \mathrm{L}$ of Tris-HCl, $\mathrm{pH} 8.0 ; 150 \mathrm{mmol} / \mathrm{L}$ of $\mathrm{NaCl} ; 1 \%$ Triton $\mathrm{X}-100 ; 10 \mathrm{mg} / \mathrm{mL}$ of aprotinin; $52 \mathrm{mmol} / \mathrm{L}$ of leupeptin; $1 \mathrm{mmol} / \mathrm{L}$ of pepstatin $\mathrm{A}$; $1 \mathrm{mmol} / \mathrm{L}$ of EDTA; and $1 \mathrm{~mol} / \mathrm{L}$ of PMSF) and centrifuged $\left(10 \mathrm{~min}, 2,500 \times g\right.$ at $\left.4^{\circ} \mathrm{C}\right)$. The supernatants were centrifuged $\left(1 \mathrm{~h}, 17,500 \times g\right.$ at $\left.4^{\circ} \mathrm{C}\right)$ and then the obtained supernatants were stored at $-80^{\circ} \mathrm{C}$. The protein levels were determined using the Bradford method (4). The endometrial and myometrial parts $(20 \mu \mathrm{g})$ were dissolved in a sodium dodecyl sulphate (SDS) gelloading buffer $(50 \mathrm{mmol} / \mathrm{L}$ of Tris-HCl, $\mathrm{pH} 6.8$; $4 \%$ SDS; $20 \%$ glycerol; and 2\% $\beta$-mercaptoethanol), heated to $95^{\circ} \mathrm{C}$ for $4 \mathrm{~min}$ and separated by $10 \%$ SDSpolyacrylamide gel electrophoresis. The separated proteins were electro-blotted onto $0.22 \mu \mathrm{m}$ nitrocellulose membrane in a transfer buffer $(20 \mathrm{mmol} / \mathrm{L}$ of Tris- $\mathrm{HCl}$ buffer, $\mathrm{pH} 8.2 ; 150 \mathrm{mmol} / \mathrm{L}$ of glycine; $20 \%$ methanol; and $0.05 \%$ SDS). The nonspecific binding sites were blocked by incubation with $5 \%$ fat-free dried milk in Tris buffered saline-Tween 20 (TBS-T) buffer at room temperature for $1.5 \mathrm{~h}$. The nitrocellulose membranes were incubated overnight at $4^{\circ} \mathrm{C}$ with primary polyclonal antibodies comprising rabbit anti-human M2R antibody (in 1:1,000 dilution, cat. no. 313310, Acris Antibodies, Germany), rabbit anti-human M3R antibody (in 1:1,000 dilution, cat. no. NBP2-19444, Novus Biologicals, USA), rabbit anti-human subunit of a-7 nAChR antibody (in dilution 1:800, cat. no. BP2143, Acris Antibodies), and rabbit GAPDH antibody (in 1:5,000 dilution, cat. no. G9545, Sigma-Aldrich, USA).

Table 1. TaqMan assays used in this study

\begin{tabular}{lll}
\hline Symbol & Name & Assay No. \\
\hline CHRM2 & cholinergic receptor muscarinic 21 & Ss03383697_u1 \\
CHRM3 & cholinergic receptor muscarinic 3 & Ss03387661_u1 \\
GAPDH & glyceraldehyde-3-phosphate dehydrogenase & Ss03375435_u1 \\
ACTB & B-actin & Ss03376081_u1 \\
HPRT & hypoxanthine guanine phosphoribosyl transferase & Ss03388274_m1 \\
\hline
\end{tabular}


After being washed in TBS-T buffer, the nitrocellulose membranes with biotinylated goat antirabbit IgG (in 1:3,000 dilution, Vectastain Elite ABCHRP Kit, cat. no. PK-6100, Vector Labs, USA) were incubated for $1 \mathrm{~h}$ at room temperature. Antibody binding was visualised by incubation with a freshly prepared mixture of 3, 3'diaminobenzidine tetrahydrochloride (DAB, cat. no. D5637, Sigma-Aldrich) and $\mathrm{H}_{2} \mathrm{O}_{2}$ in Trisbuffered saline ( $\mathrm{pH}$ 7.2) for 3-4 min. Images were captured and quantitated using Quantity-One software and a VersaDoc 4000M imaging system (Bio-Rad Laboratories, USA). The band density was normalised based on GAPDH protein expression.

Immunofluorescence. To determine the tissue distribution of M2R, M3R, and $\alpha-7 \mathrm{nAChR}$, fragments of uterine horns were cut in a cryostat (Reichert-Jung, Germany). Next, 10- $\mu \mathrm{m}$-thick sections were subjected to the routine single-immunofluorescence method. After air-drying at room temperature for $30 \mathrm{~min}$, the sections

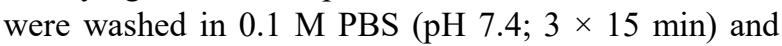
incubated in a blocking buffer containing $0.1 \mathrm{M}$ of PBS, $10 \%$ normal goat serum (MP Biomedicals, USA), $0.1 \%$ bovine serum albumin, $0.05 \%$ Thimerosal, $1 \%$ Triton X-100 (all Sigma-Aldrich, USA) and $0.01 \% \mathrm{NaN} 3$ for $1 \mathrm{~h}$ at room temperature. Next, the sections were rinsed in PBS $(3 \times 15 \mathrm{~min})$ to remove impurities and excess blocking buffer and were then incubated overnight at room temperature in a humidity chamber with the same primary antibodies as for the Western blot method against M2R, M3R, and $\alpha-7$ nAChR, all in 1:300 dilution. The next day, after washing in PBS $(3 \times 15 \mathrm{~min})$, sections were incubated with biotinylated anti-rabbit IgG (in 1:1,000 dilution, cat. no. AP132B, Chemicon International, USA) for $1 \mathrm{~h}$, at room temperature and subsequently with carbocyanine 3-conjugated streptavidin (in 1:9,000 dilution, cat. no. 016160084, Jackson ImmunoResearch Labs, USA) for $1 \mathrm{~h}$, at room temperature. The primary and secondary antibodies were diluted in blocking buffer free of normal goat serum. Negative control staining was accomplished by replacing the primary antibodies with the same concentration of rabbit normal IgG. The kind of uterine cells displaying immunoreactivity for the relevant receptors and intensity of staining were evaluated by two independent researchers with a BX51 microscope (Olympus Life Science Solutions, Japan) equipped with epi-fluorescence and appropriate filter sets. The results were expressed semi-quantitatively (arbitrarily) as strong $(+++)$, moderate $(++)$, weak $(+)$, or no reaction $(-)$, as reported in an earlier publication (20).

Statistical analyses. The data were found to be normally distributed using the D'Agostino-Pearson omnibus normality test. Data expressed as means \pm SEM were statistically assessed by two-way ANOVA (day and treatment) followed by the Bonferroni test (InStat, Graph Pad, USA). Differences were evaluated as significant if the probability was $\mathrm{P}<0.05$.

\section{Results}

Uterine messenger RNA expression of M2R and M3R. Following treatment with bacteria, the M2R mRNA expression in the endometrial layer was reduced in relation to the $\mathrm{Ctrl}(\mathrm{P}<0.01)$ and $\mathrm{Sal}(\mathrm{P}<0.05)$ groups (Fig. 1A). The M2R mRNA levels in the myometrium of the control, saline- and E. coli-administered uteri were similar (Fig. 1B).

In the inflamed endometrium, the content of M3R mRNA was lower than in the control $(\mathrm{P}<0.05)$ and saline-injected $(\mathrm{P}<0.01)$ uteri (Fig. $1 \mathrm{C})$. The M3R mRNA expression in the myometrial tissues of the control, saline, and E. coli-infused uteri was similar (Fig. 1D).

Uterine protein expression of M2R, M3R, and a-7 nAChR. Bands of proteins correlated with the molecular weight of M2R, M3R, and $\alpha-7 \mathrm{nAChR}-40$, 60 , and $63 \mathrm{kDa}$ (Fig. 2A and B, Fig. 2C and D, and Fig. 2E and F, respectively).

The contents of M2R protein in the endometrium (Fig. 2A) and myometrium (Fig. 2B) did not differ significantly between the three studied groups.

In the inflamed endometrium, the $\mathrm{M} 3 \mathrm{R}$ protein level was decreased $(\mathrm{P}<0.001)$ in relation to the control and saline-treated organs (Fig. 2C). The level of M3R protein in myometrial samples of the E. coli-injected uteri was higher $(\mathrm{P}<0.001)$ than in those which were controls and saline-treated, while this level was reduced $(\mathrm{P}<0.001)$ in the myometrium of the saline-treated uteri in relation to the control organs (Fig. 2D).

The expression of $\alpha-7$ nAChR protein in the endometrium of the saline-injected uteri was enhanced $(\mathrm{P}<0.001)$ as compared to the control and E. coli-treated sections (Fig. 2E). The level of $\alpha-7 \mathrm{nAChR}$ protein was reduced $(\mathrm{P}<0.001)$ in the myometrium following intrauterine bacteria infusion in relation to other groups (Fig. 2F).

Uterine localisation of M2R, M3R, and $\alpha-7$ nAChR. Immunofluorescent scoring for $\mathrm{M} 2 \mathrm{R}, \mathrm{M} 3 \mathrm{R}$, and a-7 nAChR immunostaining in the Ctrl, Sal, and E. coli groups is given in Table 2. Replacement of primary antibodies by normal rabbit IgG led to complete elimination of the immunostaining for M2R (Fig. 3Q), M3R (Fig. 3R), and $\alpha-7$ nAChR (Fig. 4I). Expression of the examined receptors was found in the luminal and glandular epithelium, blood vessels, and myometrial muscle cells of the control (Fig. 3A, E, I, and M, Fig. 4A and E), saline-infused (Fig. 3C, G, K, and O, Fig. 4C and G), and bacteria-infused (Fig. 3B, D, F, H, J, L, N, and $\mathrm{P}$ and Fig. 4B, D, F, and $\mathrm{H}$ ) uteri. In relation to the Ctrl (Fig. 3I and M) and Sal (Fig. 3O) groups, the M3R staining in the E. coli group was weaker in the luminal epithelial cells (Fig. 3J) and in the muscle layer of a portion of the endometrial arteries (Fig. 3N), while it was stronger in the stromal cells and muscle cells of the circular and longitudinal layers of the myometrium 
(Fig. 3P). In the inflamed uteri, weaker $\alpha-7 \mathrm{nAChR}$ staining was displayed by the luminal epithelium cells (Fig. 4B) than in the uteri of the Ctrl (Fig. 4A) and Sal groups. The intensity of M2R immunoreactivity in the uterine cells did not differ between the Ctrl (Fig. 3A and E), Sal (Fig. 3C and G) and E. coli (Fig. 3B, D, F and $\mathrm{H}$ ) groups.
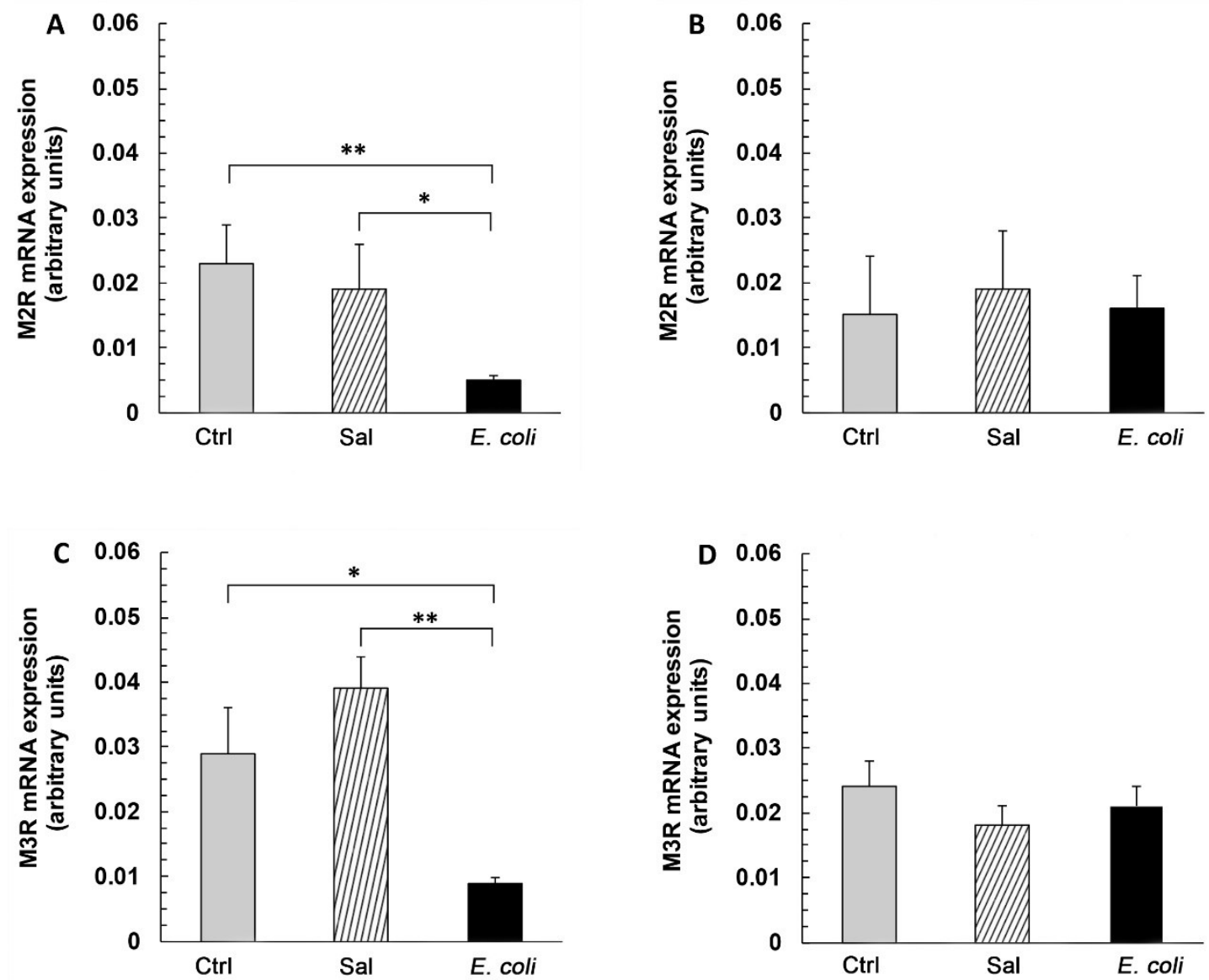

Fig. 1. Messenger RNA levels of M2R (A and B) and M3R (C and D) in the endometrium (A and C) and myometrium (B and D) of gilts from the Ctrl, Sal, and E. coli groups. Results of quantification by real-time PCR are expressed as the mean \pm SEM of ratios relative to glyceraldehyde-3-phosphate dehydrogenase $(\mathrm{GAPDH}) .{ }^{*}-\mathrm{P}<0.05$ and ${ }^{* *}-\mathrm{P}<0.01$ indicate differences between groups for the same type of receptor

Table 2. Distribution and intensity of $\mathrm{M} 2 \mathrm{R}, \mathrm{M} 3 \mathrm{R}$, and $\alpha-7 \mathrm{nAChR}$ staining in the gilt uteri of the Ctrl, Sal and E. coli groups

\begin{tabular}{|c|c|c|c|c|c|c|c|c|c|}
\hline \multirow{2}{*}{$\begin{array}{c}\text { Receptor } \\
\text { Uterine structure }\end{array}$} & \multicolumn{3}{|c|}{ M2R } & \multicolumn{3}{|c|}{ M3R } & \multicolumn{3}{|c|}{$\alpha-7 \mathrm{nAChR}$} \\
\hline & Ctrl & Sal & E. coli & Ctrl & Sal & E. coli & Ctrl & Sal & E. coli \\
\hline \multicolumn{10}{|l|}{ Endometrium } \\
\hline Luminal epithelium & $-1+$ & $-/+$ & $-/+$ & $-/+/++/+++$ & $-/+/++/+++$ & $-/+/++$ & $-/+/++$ & $-/+/++$ & $-/+$ \\
\hline Glandular epithelium & $-/+/++$ & $-/+/++$ & $-/+/++$ & $-/+/++/+++$ & $-/+/++/++$ & $-/+/++/+++$ & $-1+$ & $-/+$ & $-/+$ \\
\hline Arterial endothelium & $-/+/++$ & $-/+/++$ & $-/+/++$ & $-/+/++$ & $-/+/++$ & $-/+/++$ & $-1+$ & $-/+$ & $-/+$ \\
\hline Arterial muscle layer & $-/+$ & $-/+$ & $-/+$ & $-/+/++$ & $-/+/++$ & $-1+$ & $-/+$ & $-/+$ & $-/+$ \\
\hline Venous wall & $-/+$ & $-/+$ & $-/+$ & $-/+/++$ & $-/+/++$ & $-/+/++$ & $-/+$ & $-/+$ & $-/+$ \\
\hline Stroma & $-1+$ & $-1+$ & $-1+$ & $-/+$ & $-/+$ & $-/+/++$ & $-1+$ & $-/+$ & $-/+$ \\
\hline \multicolumn{10}{|l|}{ Myometrium } \\
\hline Muscle circular layer & $-/+/++$ & $-/+/++$ & $-/+/++$ & $-1+/++$ & $-/+/++$ & $-/+/++/+++$ & $-/+$ & $-/+$ & $-/+$ \\
\hline Muscle longitudinal layer & $-/+$ & $-/+$ & $-/+/+$ & $-/+/++$ & $-/+/++$ & $-/+/++/+++$ & $-/+$ & $-/+$ & $-/+$ \\
\hline Arterial endothelium & $-/+/++$ & $-/+/++$ & $-/+/++$ & $-/+$ & $-1+$ & $-/+$ & $-/+$ & $-/+$ & $-/+$ \\
\hline Arterial muscle layer & $-/+$ & $-1+$ & $-/+$ & $-1+$ & $-/+$ & $-1+$ & $-/+$ & $-/+$ & $-/+$ \\
\hline Venous wall & $-/+$ & $-/+$ & $-/+$ & $-/+$ & $-1+$ & $-/+$ & $-1+$ & $-/+$ & $-/+$ \\
\hline
\end{tabular}



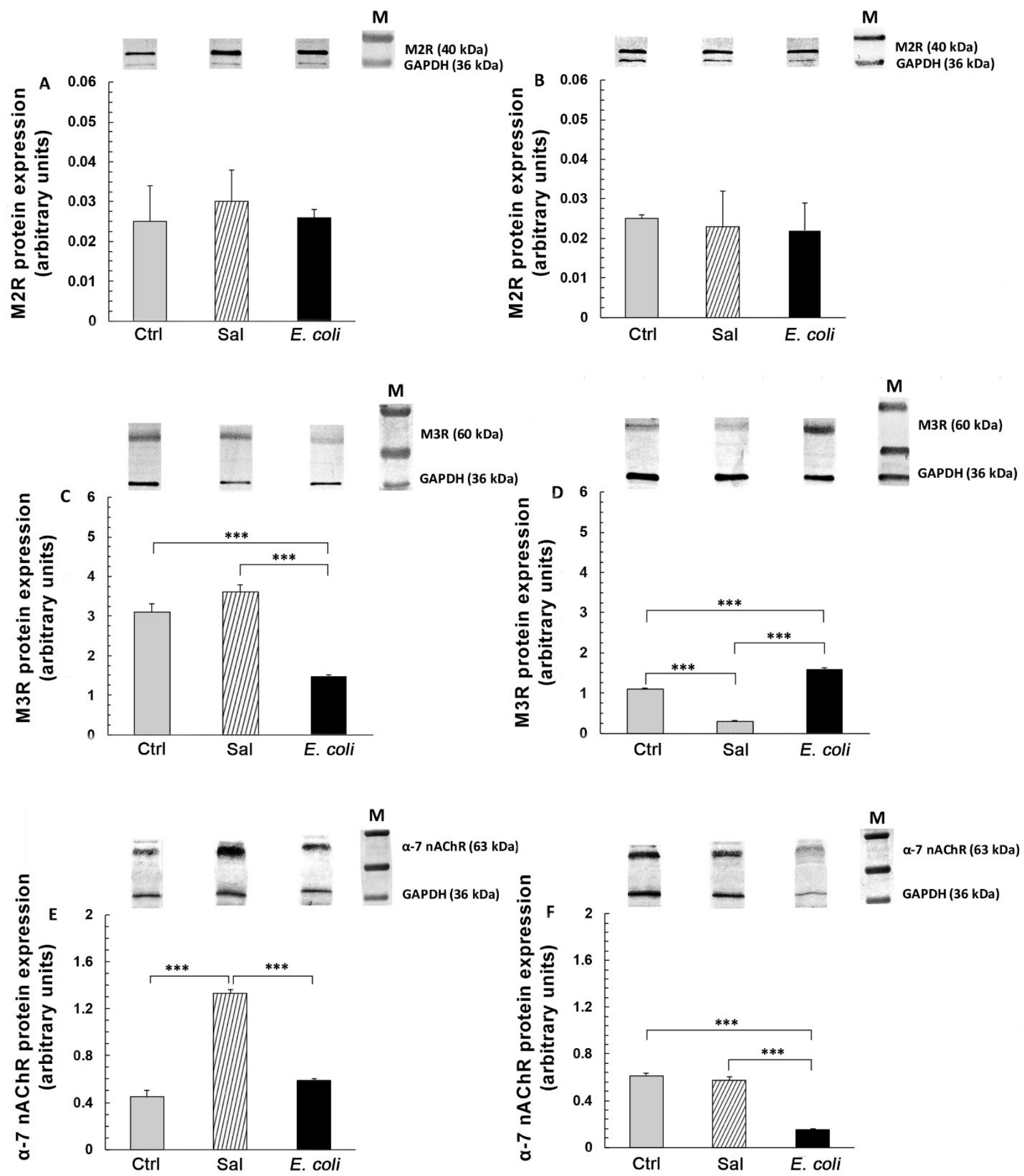

Fig. 2. Protein expression of $M 2 R$ ( $A$ and $B), M 3 R(C$ and $D)$, and $\alpha-7 \mathrm{nAChR}(\mathrm{E}$ and $\mathrm{F})$ in the endometrium (A, C and E) and myometrium (B, D and F) of gilts from the Ctrl, Sal and $E$. coli groups $(n=5$ for each group). Representative blots are shown on upper panels. The results of quantification of protein contents are expressed as the mean \pm SEM of ratios relative to glyceraldehyde-3-phosphate dehydrogenase (GAPDH). $* * *-\mathrm{P}<0.001$ indicates differences between groups for the same type of receptor. $\mathrm{M}-$ marker 

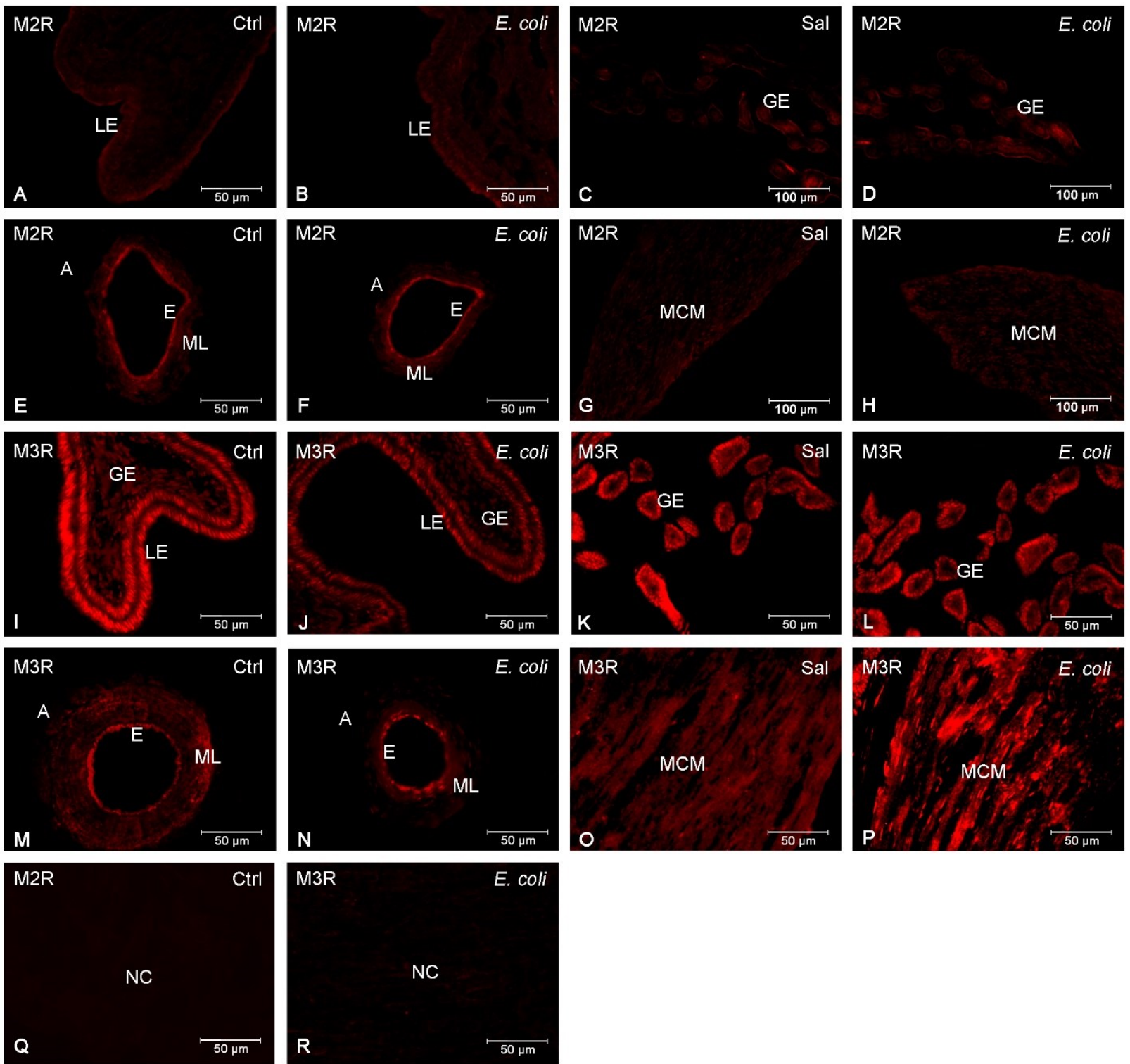

Fig. 3. Representative images of M2R (A-H) and M3R (I-P) in the uteri of gilts from the Ctrl, Sal, and E. coli groups

Image A - weak immunoexpression of M2R in the luminal epithelium of the Ctrl group

Image B - weak immunoexpression of M2R in the luminal epithelium of the E. coli group

Image $\mathrm{C}$ - moderate and weak immunoexpression of M2R in the glandular epithelium of the Sal group

Image $\mathrm{D}$ - moderate and weak immunoexpression of $\mathrm{M} 2 \mathrm{R}$ in the glandular epithelium of the $E$. coli group

Image $\mathrm{E}$ - moderate immunoexpression of M2R in the arteries of the endometrium and in the endothelium, and weak or absent immunoexpression in the muscle layer of the Ctrl group

Image F - moderate immunoexpression of M2R in the arteries of the endometrium and in the endothelium, and weak or absent immunoexpression in the muscle layer of the E. coli group

Image $\mathrm{G}$ - weak or absent immunoexpression of M2R in muscle cells of the myometrium of the Sal group

Image $\mathrm{H}$ - weak or absent immunoexpression of M2R in muscle cells of the myometrium of the $E$. coli group

Image I - strong immunoexpression of M3R in the luminal epithelium and moderate immunoexpression in the glandular epithelium of the Ctrl group

Image $\mathrm{J}$ - weak immunoexpression of M3R in the luminal epithelium and glandular epithelium of the $E$. coli group

Image $\mathrm{K}$ - strong immunoexpression of M3R in the glandular epithelium of the Sal group

Image $\mathrm{L}$ - strong immunoexpression of M3R in the glandular epithelium of the E. coli group

Image $\mathrm{M}$ - moderate immunoexpression of M3R in the arteries of the endometrium, endothelium, and muscle layer of the Ctrl group

Image $\mathrm{N}$ - weak immunoexpression of M3R in the arteries of the endometrium, endothelium, and muscle layer of the $E$. coli group

Image $\mathrm{O}$ - moderate and weak immunoexpression of M3R in the muscle cells of the myometrium of the Sal group

Image $\mathrm{P}$ - strong immunoexpression of M3R in the muscle cells of the myometrium of the $E$. coli group

Image $\mathrm{Q}$ - negative control for M2R after replacing the primary antibody with rabbit normal $\operatorname{IgG}$

Image $\mathrm{R}$ - negative control for M3R after replacing the primary antibody with rabbit normal $\mathrm{IgG}$

A - artery, E - endothelium, GE - glandular epithelium, LE - luminal epithelium, MCM - muscle cells of myometrium, ML - muscle layer, $\mathrm{NC}$ - negative control 

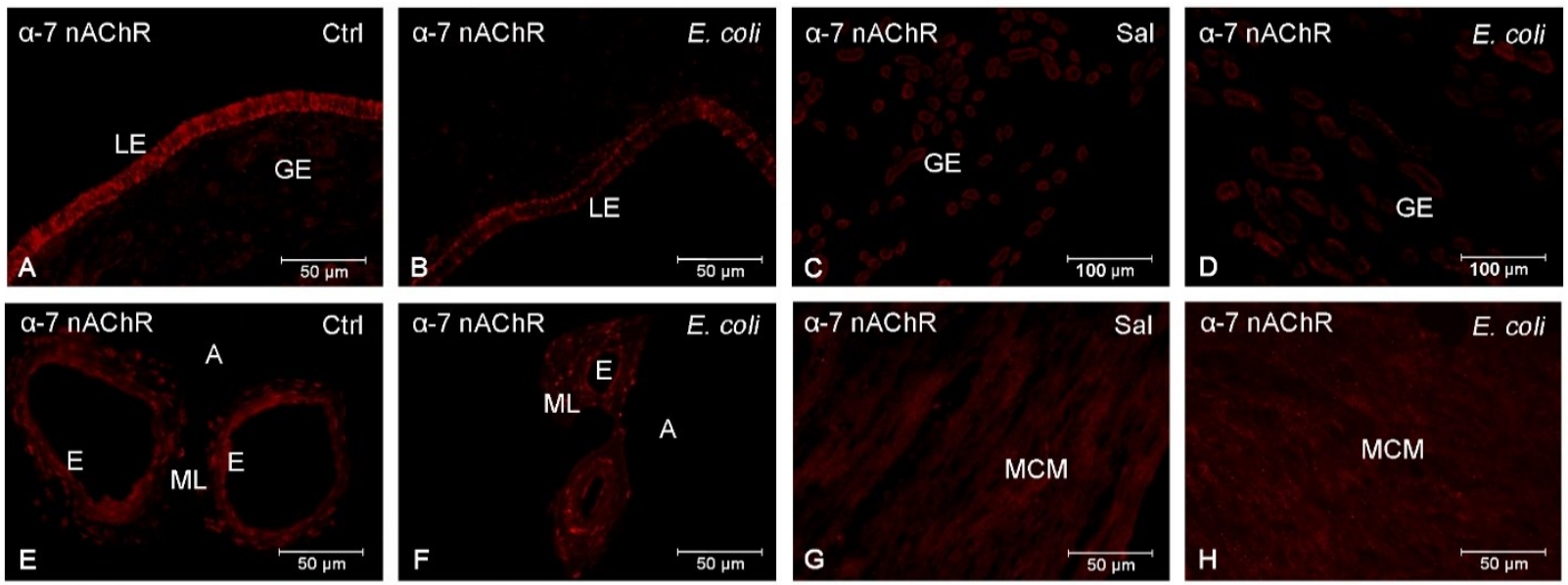

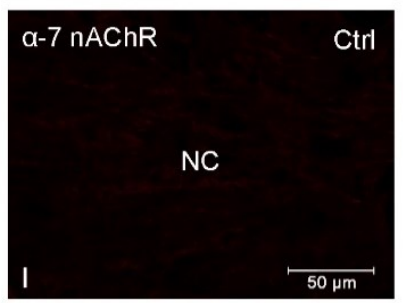

Fig.4. Representative images of $\alpha-7 \mathrm{nAChR}$ in the uteri of gilts from the control (Ctrl), saline (Sal) and E. coli (E. coli) groups

Image A - moderate immunoexpression of $\alpha-7 \mathrm{nAChR}$ in the luminal epithelium and weak immunoexpression in the glandular epithelium of the Ctrl group

Image $\mathrm{B}$ - weak immunoexpression of $\alpha-7 \mathrm{nAChR}$ in the luminal epithelium of the E. coli group

Image $\mathrm{C}$ - weak immunoexpression of $\alpha-7 \mathrm{nAChR}$ in the glandular epithelium of the Sal group

Image $\mathrm{D}$ - weak immunoexpression of $\alpha-7 \mathrm{nAChR}$ in the glandular epithelium of the $E$. coli group

Image $\mathrm{E}$ - weak or absent immunoexpression of $\alpha-7 \mathrm{nAChR}$ in the arteries of the endometrium, endothelium, and muscle layer of the Ctrl group

Image $\mathrm{F}$ - weak or absent immunoexpression of $\alpha-7 \mathrm{nAChR}$ in the arteries of the endometrium, endothelium, and muscle layer of the $E$. coli

group

Image $\mathrm{G}$ - weak immunoexpression of $\alpha-7 \mathrm{nAChR}$ in the muscle cells of the myometrium of the Sal group

Image $\mathrm{H}$ - weak immunoexpression of $\alpha-7 \mathrm{nAChR}$ in the muscle cells of the myometrium of the $E$. coli group

Image I - negative control for $\alpha-7 \mathrm{nAChR}$ after replacing the primary antibody with rabbit normal IgG

A - artery, E - endothelium, GE - glandular epithelium, LE - luminal epithelium, MCM - muscle cells of myometrium, ML - muscle layer,

$\mathrm{NC}$ - negative control

\section{Discussion}

In the experiment, the expression patterns of M2R, M3R, and $\alpha-7 \mathrm{nAChR}$ in the inflamed uteri were examined. The findings of macroscopic and histological studies of the tissue used in the research were published previously and noted severe endometritis with oedema and hyperaemia, an increased number of neutrophils, and damage to glands and/or luminal epithelium in the E. coli-administered uteri (23).

Prior to this study, investigation of ACh receptor expression in the uterus under physiological conditions had only revealed the presence of M3R in the gilt myometrium through a radioligand-binding study (17). The current study found that besides M3R, the porcine uterus also expresses $\mathrm{M} 2 \mathrm{R}$ and $\alpha-7 \mathrm{nAChR}$. It is worth mentioning that the current study is the first in which the uterine expression of $M 2 R$ in pigs has been shown, while $\alpha-7$ nAChR expression has been identified for the first time in the endometrial and myometrial tissues. The presence of M2R (mRNA and protein) was previously detected in the rat myometrium (1) as well as in a functional study in the mouse (16) and guinea pig (19) myometrial layer. The $\alpha-7 \mathrm{nAChR}$ was found in human placentas (18) and in the endometriotic foci in a mouse endometriosis model (35).

A completely new indication in the current research is that inflammation appears to lead to changes in the expression of M2R mRNA, M3R mRNA and protein, and $\alpha-7 \mathrm{nAChR}$ protein in the endometrium as well as in the expression of M3R and $\alpha-7 \mathrm{nAChR}$ protein in myometrium. Such changes in the $E$. coli group in this study were observed in relation to both the Ctrl and Sal groups, except for an alteration in $\alpha-7 \mathrm{nAChR}$ protein expression in the endometrial layer which was only different compared to the Sal group. In the current study, significant differences in the M2R mRNA and protein expression between the Ctrl and Sal groups were not revealed, which indicates that the injections of saline into the uterus did not affect this receptor level. Moreover, in both groups the levels of M3R mRNA and protein in the endometrial layer and of mRNA in the myometrial layer were similar. However, in the Sal group, the protein expression of $\alpha-7$ nAChR was increased in the endometrium and the protein expression of M3R was reduced in the myometrium in relation to the Ctrl group.

Intrauterine $E$. coli injection caused a decrease in levels of M2R mRNA, $\alpha-7$ nAChR protein and M3R 
mRNA and protein expression in the endometrial tissue. In the myometrium of bacteria-treated uteri, upregulation of M3R protein expression and downregulation of $\alpha-7$ nAChR protein expression were revealed. The current data are partly consistent with reports showing reduced expression of M2R and increased expression of $M 3 R$ in inflammatory states of the airways in the course of chronic obstructive pulmonary disease (27), induction of expression of M3R and M5R in murine fibroblasts in response to inflammation (6), and greater expression of $\alpha-7$ nAChR in severe preeclampsia placentas (18). In the present experiment, only the changes in the inflamed endometrial M3R mRNA expression in relation to the $\mathrm{Ctrl}$ and Sal groups were coincident with the product of this gene. In the myometrium, the unchanged mRNA levels of both studied muscarinic receptors were accompanied by a lack of change in $\mathrm{M} 2 \mathrm{R}$ and by a rise in M3R protein level.

The immunofluorescent studies revealed that inflammation did not affect the distribution of M2R, M3R, or $\alpha-7 \mathrm{nAChR}$ in the uterus, i.e. expression of these receptors was found in the luminal epithelium, glands, blood vessels, and myometrial muscle cells in pigs from the E. coli, Sal, and Ctrl groups. This suggests that under physiological and inflammatory conditions, these uterine structures may be binding sites for ACh neuronally released and/or secreted by these cells as an autocrine or paracrine hormone, which was indicated in the airway system (7). Moreover, in the inflamed uteri, this study found weaker immunoreaction for M3R and $\alpha-7 \mathrm{nAChR}$ in part of the luminal epithelium cells, and for M3R in muscle cells in a portion of the arteries in the endometrium as well as more intensive staining for M3R in a part of the stromal and myometrial muscle cells. These findings indicate that during uterine inflammation, the luminal epithelium and endometrial arteries are sites of decreased ACh effect and that the main target cells for this neurotransmitter are the stromal and myometrial muscle cells.

This may indicate that the alterations in the expression of M2R mRNA, M3R mRNA and protein, and $\alpha-7 \mathrm{nAChR}$ protein found in the present experiment could be consequences of bacteria administration and the developed inflammation. The factors that cause the changes in M2R, M3R, and $\alpha-7$ nAChR expression might include lipopolysaccharide (LPS) released from bacteria (22) and cytokines (pro-inflammatory) produced in large amounts $(8,34)$ in uterine infection. It is known that tumour necrosis factor- $\alpha(\mathrm{TNF}-\alpha)$ and interleukin- $1 \beta$ (IL-1 $\beta$ ) synergise to reduce the M2R expression in fibroblasts of human embryonic lung (HEL 299 cells) (10) and that LPS and interferon- $\gamma$ induce expression of M3R and M5R in murine fibroblasts (6). Moreover, the mAChR level in the current experiment may have been modulated by the steroid hormones, which were present in the rat myometrium under physiological conditions (36). It should be noted that in the gilts suffering from endometritis, peripheral blood levels of oestrogens and progesterone were reduced, and their androstenedione level was increased and ovarian cyclicity was disturbed (15). Moreover, the altered M2R, M3R, and $\alpha-7 \mathrm{nAChR}$ expression in the uterus with inflammation may be a consequence of the changes in concentration of these receptor ligands in the uterus. The population of cholinergic nerve fibres in the pig uterus with inflammation depends on the type of structure (unpublished data). It was also reported that carbachol, a cholinomimetic drug, reduces M2R expression in HEL 299 cells (3). In addition, transregulation of M2R by $\beta 2$-adrenoreceptor stimulation at the protein level in these cells was also demonstrated (28).

This may indicate that the changes in expression of M2R mRNA, M3R mRNA and protein, and $\alpha-7 \mathrm{nAChR}$ protein in the inflamed gilt endometrial layer may be significant for the modulation of the inflammation by ACh. Decreased levels of M2R mRNA expression and M3R mRNA and protein expression, as well as weaker staining for M3R in the luminal epithelium and arterial muscle layer in this tissue, suggest limited proinflammatory ACh effect. However, in the inflamed endometrium, stronger immunoreaction for M3R was shown in the stromal cells, which indicated that these cells participate in the pro-inflammatory activity of ACh. As demonstrated previously in relation to the pathophysiology of airway diseases, via M2R and M3R ACh potentiates neutrophil migration and leukotriene $B_{4}$ $\left(\mathrm{LTB}_{4}\right)$ release from sputum cells $(27)$ and the secretion of both IL-8 and LTB $_{4}$ from bronchial epithelial cells (26). In turn, downregulation of $\alpha-7 \mathrm{nAChR}$ protein expression and weaker immunoreactivity for this receptor in the luminal epithelium may be instrumental in a reduction of the anti-inflammatory effect of ACh and may contribute to maintaining inflammation. It is known that $\alpha-7 \mathrm{nAChR}$ agonists led to inhibition of LPSinduced TNF- $\alpha$ release during lung inflammation (9) and inhibition of TNF- $\alpha$ and IL- $1 \beta$ expression in immune cells (35). However, it should be added that the ACh effect on the inflammatory process in the uterus through M2R, M3R and $\alpha-7$ nAChR may depend not only on their level of expression but also on their sensitivity, which requires further study. Other needs for investigation concern the expression of M2R, M3R, and a-7 nAChR in those immune cells (including neutrophils) of which the population in the inflamed uterus is increased (23), as well as the mechanism of ACh receptor action on synthesis in and secretion of inflammatory mediators by uterine cells. Such research will more precisely determine the role of M2R, M3R, and $\alpha-7 \mathrm{nAChR}$ in interaction with $\mathrm{ACh}$.

In reference to the myometrium of $E$. coli-treated gilts, the current study found a rise in the level of M3R protein expression and stronger immunoreaction for this receptor in the muscle cells as well as a drop in the level of $\alpha-7 \mathrm{nAChR}$ protein expression. As revealed in a foregoing study using the same uteri as the current experiment, ACh increases the contractile activity of healthy uteri via MR2 and MR3, while it decreases the contractility of inflamed uteri (11). Thus, despite the 
higher content of M3R in the myometrium after $E$. coli injection, receptor stimulation by ACh may be too small to increase the contractile activity of the inflammatory uterus. It may be significant for the accumulation of inflammatory exudate in the cavity of the uterus and influence the course and/or consequences of the inflammation. It is possible that the reduced contractility of the uterus with inflammation results from the alterations in M3R sensitivity.

In conclusion, this study demonstrates the changed expression of M2R, M3R, and $\alpha-7 \mathrm{nAChR}$ in the pig uterus with $E$. coli-induced inflammation. These changes may determine ACh influence on the course of the inflammatory process and functions of inflamed uterus. Further studies are needed to identify the mechanisms underlying changes in M2R, M3R, and $\alpha-7$ nAChR expression and their participation in the activity of the inflamed uterus. Finally, the rises and falls in the expression of these receptors found in this research can be used to develop suitable drugs to restore normal uterine function.

Conflict of Interests Statement: The authors declare that there is no conflict of interests regarding the publication of this article.

Financial Disclosure Statement: The research was funded by the National Science Centre, Poland (grant no. 2014/15/B/NZ5/O3572) as well as the Polish Academy of Sciences.

Animal Rights Statement: The Local Ethics Committee of the University of Warmia and Mazury in Olsztyn approved all procedures (consent no. 65/2015).

\section{References}

1. Abdalla F.M., Maróstica E., Picarelli Z.P., Abreu L.C., Avellar M.C., Porto C.S.: Effect of estrogen on muscarinic acetylcholine receptor expression in rat myometrium. Mol Cell Endocrinol 2004, 213, 139-148.

2. Andersen C.L., Jensen J.L., Ørntoft T.F.: Normalization of real-time quantitative reverse transcription-PCR data: a model-based variance estimation approach to identify genes suited for normalization, applied to bladder and colon cancer data sets. Cancer Res 2004, 64, 5245-5250.

3. Barnes P.J., Haddad E.B., Rousell J.: Regulation of muscarinic M2 receptors. Life Sci 1997, 60, 1015-1021.

4. Bradford M.M.: A rapid and sensitive method for the quantitation of microgram quantities of protein utilizing the principle of protein-dye binding. Anal Biochem 1976, 72, 248-254.

5. Caulfield M.P., Birdsall N.J.: International Union of Pharmacology. XVII. Classification of muscarinic acetylcholine receptors. Pharmacol Rev 1998, 50, 279-290.

6. Espanol A.J., Maddaleno M.O., Lombardi M.G., Cella M., Martínez Pulido P., Sales M.E.: Treatment with LPS plus INF- $\gamma$ induces the expression and function of muscarinic acetylcholine receptors, modulating NIH3T3 cell proliferation: participation of NOS and COX. Br J Pharmacol 2014, 171, 5154-5167.

7. Fujii T., Mashimo M., Moriwaki Y., Misawa H., Ono S., Horiguchi K., Kawashima K.: Expression and function of the cholinergic system in immune cells. Front Immunol 2017, 8, 1085.
8. Gabler C., Drillich M., Fischer C., Holder C., Heuwieser W., Einspanier R.: Endometrial expression of selected transcripts involved in prostaglandin synthesis in cows with endometritis. Theriogenology 2009, 71, 993-1004.

9. Giebelen I.A., van Westerloo D.J., LaRosa G.J., de Vos A.F., van der Poll T.: Local stimulation of alpha-7 cholinergic receptors inhibits LPS-induced TNF-alpha release in the mouse lung. Shock 2007, 28, 700-703.

10. Haddad E.B., Rousell J., Lindsay M.A., Barnes P.J.: Synergy between tumor necrosis factor alpha and interleukin lbeta in inducing transcriptional down-regulation of muscarinic M2 receptor gene expression. Involvement of protein kinase A and ceramide pathways. J Biol Chem 1996, 20, 32586-32592.

11. Jana B., Całka J., Bulc M., Piotrowska-Tomala K.K.: Participation of acetylcholine and its receptors in the contractility of inflamed porcine uterus. Theriogenology 2020, 143, 123-132.

12. Jana B., Czarzasta J., Jaroszewski J.: Synthesis of leukotrienes in porcine uteri with endometritis induced by infection with Escherichia coli. Reprod Fertil Dev 2014, 26, 1007-1016.

13. Jana B., Jaroszewski J., Czarzasta J., Włodarczyk M., Markiewicz W.: Synthesis of prostacyclin and its effect on the contractile activity of the inflamed porcine uterus. Theriogenology 2013, 79, $470-485$.

14. Jana B., Kozłowska A., Andronowska A., Jedlińska-Krakowska M. The effect of tumor necrosis factor- $\alpha$ (TNF- $\alpha$ ), interleukin (IL)- $1 \beta$ and IL- 6 on chorioamnion secretion of prostaglandins (PG)F2 $\alpha$ and E2 in pigs. Reprod Biol 2008, 8, 57-68

15. Jana B., Kucharski J., Ziecik A.J.: Effect of intrauterine infusion of Escherichia coli on hormonal patterns in gilts during the oestrous cycle. Reprod Nut Dev 2004, 44, 37-48.

16. Kitazawa T., Hirama R., Masunaga K., Nakamura T., Asakawa K., Cao J., Teraoka H., Unno T., Komori S., Yamada M., Wess J., Taneike T.: Muscarinic receptor subtypes involved in carbacholinduced contraction of mouse uterine smooth muscle. Naunyn Schmiedebergs Arch Pharmacol 2008, 377, 503-513.

17. Kitazawa T., Uchiyama F., Hirose K., Taneike T.: Characterization of the muscarinic receptor subtype that mediates the contractile response of acetylcholine in the swine myometrium. Eur J Pharmacol 1999, 367, 325-334.

18. Kwon J.Y., Kim Y.H., Kim S.H., Kang M.H., Maeng Y.S., Lee K.Y., Park Y.W.: Difference in the expression of alpha 7 nicotinic receptors in the placenta in normal versus severe preeclampsia pregnancies. Eur J Obstet Gynecol Reprod Biol 2007, 132, 35-39.

19. Leiber D., Marc S., Harbon S.: Pharmacological evidence for distinct muscarinic receptor subtypes coupled to the inhibition of adenylate cyclase and to the increased generation of inositol phosphates in the guinea pig myometrium. J Pharmacol Exp Ther 1990, 252, 800-809.

20. Levanti M.B., Germana A., Abbate F., Montalbano G., Vega J.A., Germana G.: TrkA and p75NTK in the ovary of adult cow and pig. J Anat 2005, 207, 93-96.

21. Majewski M., Sienkiewicz W., Kaleczyc J., Mayer B., Czaja K., Lakomy M.: The distribution and co-localization of immunoreactivity to nitric oxide synthase, vasoactive intestinal polypeptide and substance $\mathrm{P}$ within nerve fibres supplying bovine and porcine female genital organs. Cell Tissue Res 1995, 281 , 445-464.

22. Mateus L., Lopes da Costa L., Diniz P., Ziecik A.J.: Relationship between endotoxin and prostaglandin (PGE2 and PGFM) concentrations and ovarian function in dairy cows with puerpertal endometritis. Anim Reprod Sci 2003, 76, 143-154.

23. Meller K.A., Całka J., Kaczmarek M., Jana B.: Expression of alpha and beta adrenergic receptors in the pig uterus during inflammation. Theriogenology 2018, 119, 96-104.

24. Pena V.B., Bonini I.C., Antollini S.S., Kobayashi T., Barrantes F.J.: alpha 7-type acetylcholine receptor localization and its modulation by nicotine and cholesterol in vascular endothelial cells. J Cell Biochem 2011, 112, 3276-3288.

25. Pesic S., Grbovic L., Stoiljkovic M., Nikolic V., Djokic J.: Functional characterization of the muscarinic receptors involved 
in endothelium-dependent relaxation in isolated canine uterine artery. J Vet Pharmacol Ther 2009, 32, 109-115.

26. Profita M., Bonanno A., Siena L., Ferraro M., Montalbano A.M., Pompeo F., Riccobono L., Pieper M.P., Gjomarkaj M.: Acetylcholine mediates the release of IL-8 in human bronchial epithelial cells by a NFkB/ERK-dependent mechanism. Eur J Pharmacol 2008, 17, 145-153.

27. Profita M., Giorgi R.D., Sala A., Bonanno A., Riccobono L., Mirabella F., Gjomarkaj M., Bonsignore G., Bousquet J., Vignola A.M.: Muscarinic receptors, leukotriene B4 production and neutrophilic inflammation in COPD patients. Allergy 2005, 60, 1361-1369.

28. Rousell J., Haddad E.B., Mak J.C., Webb B.L., Giembycz M.A., Barnes P.J.: Beta-adrenoceptor-medicated down-regulation of M2 muscarinic receptors: role of cyclic adenosine 5'-monophosphatedependent protein kinase and protein kinase. C Mol Pharmacol 1996, 49, 629-635.

29. Safronova V.G., Vulfius C.A., Shelukhina I.V., Mal'tseva V.N., Berezhnov A.V., Fedotova E.I., Miftahova R.G., Kryukova E.V., Grinevich A.A., Tsetlin V.I.: Nicotinic receptor involvement in regulation of functions of mouse neutrophils from inflammatory site. Immunobiology 2016, 221, 761-772.

30. Tummaruk P., Kesdangsakonwut S., Prapasarakul N., Kaeoket K.: Endometritis in gilts: reproductive data, bacterial culture, histopathology, and infiltration of immune cells in the endometrium. Comp Clin Pathol 2010, 19, 575-584.

31. Wasowicz K., Majewski M., Lakomy M.: Distribution of neurons innervating the uterus of the pig. J Auton Nerv Syst 1998, 25, $13-22$
32. Wazea S.A., Wadie W., Bahgat A.K., El-Abhar H.S.: Galantamine anticolitic effect: role of alpha-7 nicotinic acetylcholine receptor in modulating Jak/STAT3, NF-kB/HMGB1/RAGE and p-AKT/Bcl-2 pathways. Sci Rep 2018, 8, 5110.

33. Wessler I.K., Kirkpatrick C.J.: Acetylcholine beyond neurons: the non-neuronal cholinergic system in humans. Br J Pharmacol 2008, $154,1558-1571$.

34. Woodward E.M., Christoffersen M., Campos J., Betancourt A., Horohov D., Scoggin K.E., Troedsson M.H.: Endometrial inflammatory markers of the early immune response in mares susceptible or resistant to persistent breeding-induced endometritis. Reproduction 2013, 145, 289-296.

35. Yamada-Nomoto K., Yoshino O., Akiyama I., Ushijima A., Ono Y., Shima T., Nakashima A., Hayashi S., Kadowaki M., Osuga Y., Saito S.: Alpha-7 nicotinic acetylcholine receptor (nAChR) agonist inhibits the development of endometriosis by regulating inflammation. Am J Reprod Immunol 2016, 76, 491-498.

36. Yasuda K., Sumi G., Kanamori C., Nakajima T., Tsuzuki T., Cho H., Nishigaki A., Okada H., Kanzaki H.: Effects of ovarian hormone treatment on the gene expression of muscarinic acetylcholine receptors in the ovariectomized rat myometrium. J Steroid Biochem Mol Biol 2014, 143, 81-89.

37. Zhao S., Fernald R.D.: Comprehensive algorithm for quantitative real-time polymerase chain reaction. J Comput Biol 2005, 12, 1047-1064. 